Original Research

\title{
Hypnotherapy and Yoga Combination Decrease the Anxiety of Patients in Elective Preoperative
}

\author{
Basir Basir'1, Sidik Awaludin², and Arif Imam Hidayat ${ }^{2}$ \\ 1Student of School of Nursing, Faculty of Health Sciences, Jendral Soedirman University, Purwokerto, Indonesia \\ ${ }^{2}$ Lecturer of School of Nursing, Faculty of Health Sciences, Jendral Soedirman University, Purwokerto, Indonesia
}

\begin{abstract}
Introduction: Surgery is an experience that can cause anxiety, which, if not treated well, will cause some side effects. One of the forms of nonpharmacological therapy is hypnotherapy and yoga combination therapy. This study aimed to determine the effect of hypnotherapy and yoga combination therapy on anxiety scores in elective preoperative patients.

Methods: This study used a quasi-experimental pretest and posttest with control group design. This study involved 17 respondents in the intervention group and 17 respondents in the control group. The sampling technique used consecutive sampling. Data collection used the instruments of The Amsterdam Preoperative Anxiety and Information Scale (APAIS). The statistical test used was the MannWhitney test.

Results: The average age of respondents was 36.65 years old. In a majority, they were junior high school graduates who worked as employee. The major type of operation was tumor excision. The average anxiety scores before treatment in the intervention group were 14.71 (moderate anxiety) and decreased after being given hypnotherapy and yoga combination therapy to 9.47 (mild anxiety). The average anxiety scores before treatment in the control group were 15.71 (moderate anxiety) and decreased after deep breathing therapy to 13.76 (moderate anxiety). The difference test in anxiety scores of the intervention and control groups obtained p-value 0.015 .
\end{abstract}

Conclusion: Hypnotherapy and yoga combination therapy can reduce anxiety scores in elective preoperative patients.

\section{ARTICLE HISTORY}

Received: March 18, 2020

Accepted: May 8, 2020

\section{KEYWORDS}

anxiety; deep breathing; hypnotherapy; preoperative; yoga

\section{CONTACT}

Basir Basir

$\bowtie$ basirigd118@gmail.com

$\equiv$ Faculty of Health Sciences, Jendral Soedirman University, Purwokerto, Indonesia

Cite this as: Basir, B., Awaludin, S., \& Hidayat, A. I. (2020). Hypnotherapy and Yoga Combination Decrease the Anxiety of Patients in Elective Preoperative. Jurnal Ners, 15(1). 79-84. doi:http://dx.doi.org/10.20473/in.v15i1.18291

\section{INTRODUCTION}

Surgery is all medical treatments that use invasive methods by opening or displaying parts of the body to be treated (Sjamsuhidajat \& Jong, 2010). The surgery phase consists of pre, intra and post operative. The pre-operative stage is the initial stage of the surgical procedure, including the decision on the operation until the act of operation itself (Maryunani, 2014).

World Health Organization (WHO) data shows a significant increase in the number of patients who are undergoing operations. Data in 2011 recorded 140 million patients in all hospitals in the world, while data in 2012 increased to 148 million patients. In 2012, operation treatments were measured in
Indonesia and recorded 1.2 million patients (Hartoyo, 2015).

Preoperative anxiety impacts physiological and psychological responses. If preoperative anxiety is not handled well, it has some side effects such as sweating and frequent urination, in addition to which the patient will also experience anxiety or tension, changes in hemodynamic status, and it can continue to postoperative which can affect the immune response, causing longer recovery and longer healing in the wound after surgery (Gunawan \& Kristinawati, 2018; Pereira, Figueiredo-braga \& Carvalho, 2015).

Internal and external factors can affect preoperative patient anxiety. Internal factors consist of gender, age, level of knowledge, personality type, environment, and situation, while external factors 
consist of the type of work, family, threats to the selfsystem, and threats to physical integrity (Yusuf, Fitryasari, \& Nihayati, 2015).

Anxiety management is generally managed with pharmacological and non-pharmacological therapy. Hawari (2001) described antidepressants and antianxiety medicines (anxiolytic) as pharmacological treatments. The use of antidepressants and antianxiety medicines can help reduce anxiety, but it has negative effects such as drowsiness, breathing difficulty, and affects the recovery duration of operation patients (Bradt, Dileo, \& Shim, 2013). Nonpharmacological therapies that can help reduce preoperative anxiety are hypnotherapy and yoga.

Research conducted by Lestari and Putri (2018) found that the combination of self-hypnosis and yoga exercises was effective in reducing anxiety. Hypnotherapy physiologically makes the body relax so that it can increase endorphins, which can reduce anxiety. It also makes the body feel comfortable and calm, while yoga can increase gamma amino butyric acids (GABA) which function to reduce arousal and aggression, anxiety, and are active in the function of excitation (Lestari \& Putri, 2018; Yulinda, Purwaningsih, \& Sudarta, 2017). Hypnotherapy method is to change the patients' ways of thinking using relaxation techniques, suggestions, while yoga uses the integration of a series of physical, mental health, mind movements, and is done continuously and regularly (, 2018; Cahyadi 2017). Hypnotherapy and yoga are therapies that both cause a relaxing effect. When the body relaxes, the endorphins increase, which is beneficial to reduce anxiety and to make the patient feel comfortable and calm. Hypnotherapy is expected to retain suggestions that have long-term effects, so that the therapeutic effects of combination hypnotherapy and yoga can maximally handle anxiety.

Medical record data were from $\mathrm{Hj}$. Anna Lasmanah Regional Public Hospital Banjarnegara with 9916 patients treated in poly operation during 2018 and $27 \%$ of patients were scheduled elective operations from a poly operation. The results of a preliminary study of 10 elective operation patients showed that $90 \%$ of patients expressed anxiety in facing the planned operation. Anxious feelings are such as fear of operation and fear of something unexpected happening during operation. Anxiety management performed by nurses in preoperative patients was in using deep breathing techniques. From the results of the evaluation, seven patients said they were still anxious after being given deep breathing therapy. As the majority of patients still feel anxiety after deep breathing therapy, there is a need for new therapies that can help reduce anxiety. One of the therapies is a combination therapy of hypnotherapy and yoga which is expected to be more effective in reducing anxiety scores. This research combines hypnotherapy and yoga which are complementary therapies that must be developed in the field of nursing. Based on the background phenomena above, it is necessary to study these. This study aimed to determine the effect of the combination of hypnotherapy and yoga on anxiety scores in elective preoperative patients at $\mathrm{Hj}$. Anna Lasmanah Regional Public Hospital Banjarnegara.

\section{MATERIALS AND METHODS}

The study design used a quasi-experimental pre and posttest control group design. The population of this study was elective preoperative patients at $\mathrm{Hj}$. Anna Lasmanah Regional Public Hospital Banjarnegara. The sampling technique was consecutive, which refers to the inclusion and exclusion criteria set by the researcher. Inclusion criteria: re elective surgery patients from surgical polyclinic, do not have a hearing problem, ages range from 18 - 65 years old, have composite consciousness and not experiencing mental disorders, willing to be a respondent, firsttime experience operation, and their last education backgrounds are elementary and junior high school. Exclusion criteria: the patient is experiencing a worsening condition and requires immediate surgery, the patient resigns from being a respondent during the research process, and the patient experiences moderate to severe pain during the research process. The sample size was 34 respondents with 17 respondents as the intervention group and 17 respondents as a control group. This study used the Amsterdam Preoperative Anxiety And Information Scale (APAIS) instrument, which had been tested for validity and reliability by Firdaus (2014) on 102 preoperative respondents with the following results: The validity test of the APAIS instrument showed the $r$ value for question 1 (0.864), 2 (0.773), 3 (840), 4 (0.868), 5 (829) and 6 (849). Question correlation had a good total value of $r>0.7$. APAIS instrument reliability showed consistent internal results (Cronbach's alpha). Cronbach's alpha value for anxiety component (questions 1, 2, 4, and 5) obtained 0.825, while Cronbach's alpha value for information necessity component (questions 3 and 6) was obtained as 0.863 . Good Cronbach's alpha value ranged from 0.7 to 0.9 . Researchers conducted an anxiety assessment pretest to respondents using APAIS questionnaire, the experimental group received a combination of hypnotherapy and yoga therapy one by one, then respondents received therapy for 25 minutes, including yoga for 10 minutes and hypnotherapy for 15 minutes, while, in the first control group, they received deep breathing therapy 
Table 1. Respondents' Characteristics $(n=34)$

\begin{tabular}{|c|c|c|c|c|c|}
\hline \multirow{2}{*}{ Characteristics } & \multicolumn{2}{|c|}{ Intervention } & \multicolumn{2}{|c|}{ Control } & \multirow[t]{2}{*}{$p$-value } \\
\hline & $\mathbf{n}$ & $(\%)$ & $\mathbf{n}$ & $(\%)$ & \\
\hline \multicolumn{6}{|l|}{ Gender } \\
\hline Male & 8 & 44.4 & 10 & 55.6 & 0.492 \\
\hline Female & 9 & 56.2 & 7 & 43.8 & \\
\hline \multicolumn{6}{|l|}{ Education } \\
\hline Elementary School & 7 & 46.7 & 8 & 53.3 & 0.730 \\
\hline Junior High School & 10 & 52.6 & 9 & 47.4 & \\
\hline \multicolumn{6}{|l|}{ Job } \\
\hline Farmer & 4 & 40 & 6 & 60 & \\
\hline Housewife & 6 & 54.5 & 5 & 45.5 & 0.753 \\
\hline Employee & 7 & 53.8 & 6 & 46.2 & \\
\hline \multicolumn{6}{|l|}{ Surgery Type } \\
\hline Mama Tumor Biopsy Excision & 4 & 50 & 4 & 50 & \\
\hline BPH Prostatectomy & 2 & 40 & 3 & 60 & 0.938 \\
\hline Appendectomy & 3 & 50 & 3 & 50 & \\
\hline Tumor Biopsy Excision & 6 & 60 & 4 & 40 & \\
\hline \multirow{2}{*}{ Hernia Repair } & 2 & 40 & 3 & 60 & \\
\hline & Mean & & SD & & $p$-value \\
\hline Age & 36.65 & & 13.919 & & 0.338 \\
\hline
\end{tabular}

Table 2. Description of Anxiety Mean Scores

\begin{tabular}{|c|c|c|c|c|}
\hline Anxiety & Mean (SD) & Median & Min-Max & p-value \\
\hline Pretest Intervention $(\mathrm{n}=17)$ & $14.71(4.135)$ & 15 & $6-22$ & \multirow{2}{*}{0.554} \\
\hline Pretest Control $(n=17)$ & $15.71(5.520)$ & 17 & $6-24$ & \\
\hline Pretest Intervention $(\mathrm{n}=17)$ & $14.71(4.135)$ & 15 & $6-22$ & \multirow{2}{*}{0.001} \\
\hline Posttest Intervention $(n=17)$ & $9.47(3.223)$ & 8 & $6-15$ & \\
\hline Pretest Control $(n=17)$ & $15.71(5.520)$ & 17 & $6-24$ & \multirow{2}{*}{0.002} \\
\hline Posttest Control $(\mathrm{n}=17)$ & $13.76(5.142)$ & 14 & $6-24$ & \\
\hline Posttest Intervention $(\mathrm{n}=17)$ & $9.47(3.223)$ & 8 & $6-15$ & \multirow{2}{*}{0.015} \\
\hline Posttest Control $(\mathrm{n}=17)$ & $13.76(5.142)$ & 14 & $6-24$ & \\
\hline
\end{tabular}

for five times after the two groups did an anxiety score posttest assessment for respondents using the APAIS questionnaire. This study received ethical approval from the Faculty of Health Sciences, Jenderal Soedirman University, number: 242 / EC / KEPK / XII / 2019. Univariate data analysis was performed on the two research variables and produced data presented in the form of frequency distributions namely gender, education, job, and age using central tendency. Bivariate data analysis was performed using the Mann-Whitney test. The data normality test results obtained data were not normally distributed in the posttest intervention, $\mathrm{p}=0.021$. Homogeneity tests for the pre-groups of both groups using the Levine test results obtained $\mathrm{p}=0.554$, which means data similarity was homogenous.

\section{RESULTS}

The distribution of respondents based on the gender of the majority were men (52.9\%), the education of the majority of respondents was junior high school education (55.9\%), the majority of respondents' jobs were employees (38.2\%), the majority of operation types were excision tumor biopsy (29.4\%) and the average age of respondents was 36.65 years old. Based on the table, there were no differences in the characteristics of respondents (gender, education, job, type of operation, and age) between the intervention and control groups. Based on Table 1, it can be seen that the p-value is to determine the homogeneity of each respondent's characteristics (Table 1).

The mean score of anxiety before treatment in the intervention and control groups using the unpaired $t$ test obtained $\mathrm{p}=0.554$. Anxiety scores in both groups belonged to the moderate anxiety category (13-18). These data indicate there was no statistical difference in the mean score of anxiety scores before treatment in the intervention and control groups (Table 2).

The anxiety score in the intervention group showed the pretest with a median value of 15 , on the posttest with a median value of 8 and a significance value of $0.001(p<0.005)$. This meant that there were differences in anxiety scores before and after hypnotherapy and yoga combination therapy in the intervention group. The anxiety score in the control group showed that the pretest with a mean value of 15.71 , the posttest with a mean value of 13.76 , the average difference of 1.95 , and the significance value of $0.002(p<0.005)$. This meant that there were differences in anxiety scores before and after deep breathing therapy in the control group (Table 2).

The anxiety score in the intervention group was lower than the control group. Mann-Whitney Test results obtained a p-value of $0.015(\mathrm{p}<0.05)$, then Ho was rejected, which meant there was an effect of 
hypnotherapy and yoga combination therapy on the reduction of anxiety scores in elective preoperative patients (Table 2).

\section{DISCUSSION}

The age range of respondents in this study was between the ages of 18-65 years old $(n=34)$ with the average age of respondents in both groups 36.65 years old. Respondents in this study were classified as adults according to (Indonesian Ministry of Health (2016). The results of this study were supported by the research of Sulastri, Cahyanti, and Rahmayati (2019) showing the majority of preoperative respondents aged 36-45 years old. Age can determine a person's ability to make decisions in how they behave (Diananda, 2019).

The majority of respondents in this study were male. This result was supported by research conducted by Nurdin (2018) which stated that the majority of preoperative patients were male. In contrast, research conducted by Usnadi, Rahayu, and Praptiwi (2019) explained that the majority of respondents were female. Medical record data of $\mathrm{Hj}$. Anna Lasmanah Regional Public Hospital Banjarnegara showed the proportion of elective operation patients in 2019 male and female patients was 58:42. Men and women have different levels of anxiety in which women are more easily offended, very sensitive, and emphasize feelings, whereas men have masculine characteristics that tend to be dominant, such as active, more rational, and they are not emphasizing feelings (Niken, Armiyanti \& Arif, 2014).

This study showed that the majority of respondents had a junior high school education and was supported by the research of Usnadi, Rahayu, and Praptiwi (2019) that the majority of respondents had elementary and junior high school education. This was different from research conducted by Sulastri, Cahyanti, and Rahmayati (2019) who found that the majority of respondents had an elementary school education. The difference in the results of this study was because one's education does not affect perceptions that can cause anxiety in facing operation (Vellyana, Lestari, \& Rahmawati, 2017).

This study showed that most of the respondents were employees and was supported by the research of Rizki and Hartoyo (2019) who found that the majority of respondents' jobs were employees. This was different from the research of Usnadi, Rahayu, and Praptiwi (2019) where the majority of respondents were housewives. This difference was due to the majority of respondents in this study. The type of job that has an unstable income can affect the behavior of respondents in determining treatment, buying medicine, paying hospital costs, and paying high medical costs which will increase respondents' anxiety (Rizki \& Hartoyo, 2019). Similar results were also conducted by Vellyana, Lestari, and Rahmawati (2017) who stated that anxiety can be triggered by low-income levels and economic status.
This study showed most types of surgery as with excision of tumor biopsy. Excision biopsy was performed at $\mathrm{Hj}$. Anna Lasmanah Regional Public Hospital to strengthen the diagnosis of patients with tumors or cancer. The type of operation affects the duration of postoperative care, the seriousness of the disease, the affected body part, and the duration of recovery (Rahmayati, Asbana, \& Aprina, 2017).

The results of this study indicated that the average value of anxiety in respondents before the application of hypnotherapy and yoga combination therapy did not differ statistically compared to respondents before applying deep breathing therapy. Anxiety score in both groups belongs to the moderate anxiety category. This study was supported by the research of Rismawan, Rizal, and Kurnia (2019) in that the majority of respondents who experienced preoperative anxiety were at moderate anxiety levels. Anxiety is an emotion or feeling that arises due to the first response to psychological stress and threatens values that are meaningful to patients (Azizah, Zainuri, \& Akbar, 2016). Physical responses arising in preoperative patients who experienced moderate levels of anxiety include sweating, frequent urination, restless sleep, and waking up at night (Rismawan, Rizal, \& Kurnia, 2019).

The results of this study indicated there were significant differences between anxiety scores in patients before and after hypnotherapy and yoga combination therapy in the intervention group. Research conducted by Potié et al. (2016) explained that hypnotherapy sessions were very effective in reducing anxiety before an operation. The results of this study reinforce the research conducted by Téllez et al. (2016) who explained that hypnosis sessions for 15 minutes before an operation can increase relaxation and significantly reduce preoperative anxiety levels.

Deep breathing therapy is a nursing therapy procedure at $\mathrm{Hj}$. Anna Lasmanah Regional Public Hospital Banjarnegara as an independent nursing intervention in overcoming preoperative anxiety. The results of this study indicated that there were differences in anxiety scores before and after deep breathing therapy in the control group. Other studies related to deep breathing therapy in Nurdin's research (2018) where there were differences in anxiety levels in patients with preoperative appendicitis after doing deep breathing therapy. Research conducted by Rokawie, Sulastri, and Anita (2017) showed that there were differences in average anxiety scores before and after deep breathing in abdominal preoperative patients. This is in line with the theory of Smeltzer and Bare (2002) which stated the purposes of deep breathing relaxation were to maximize the work of alveoli ventilation, to accelerate gas exchange, to prevent lung atelectasis, to improve cough efficiency, and to reduce stress both physical stress (pain) and emotional (anxiety).

The results of this study indicated that there was an effect of decreasing anxiety scores between respondents who were given hypnotherapy and yoga 
combination therapy with respondents given deep breathing therapy. This study showed hypnotherapy combination therapy, yoga and deep breathing therapy, could all reduce anxiety scores, but for the reduction score in the intervention group using hypnotherapy and yoga combination therapy was higher than the control group using deep breathing therapy.

Hypnotherapy and yoga combination therapy were given for 25 minutes and deep breathing therapy given for five times. Both therapies were effective in reducing anxiety. The advantage of hypnotherapy and yoga combination therapy was the process of uniting aspects in human beings, such as physical, psychological, and spiritual, by giving positive suggestions; even after the hypnosis session had finished the suggestion was still recorded in the patient's subconscious mind (Kinasih, 2010; Syaripudin, 2018). Deep breathing is a procedure for treating anxiety in the $\mathrm{Hj}$. Anna Lasmanah Regional Public Hospital Banjarnegara so that researchers took deep breathing as a control. A deep breathing is as effective as hypnotherapy and yoga combination in dealing with anxiety, but the duration of the effectiveness of relaxation is longer because hypnotherapy and yoga are cognitive therapies. Research conducted by Niken, Armiyanti, andArif (2014) explained that there was the effect of reducing anxiety after being given deep breathing therapy within four hours before the patient entered the operating room and measuring anxiety again 45 minutes before the patient entered the operating room, as such an increase in anxiety scale was obtained due to external and internal stimuli that could affect preoperative patient anxiety. The study limitation was not yet controlling overall factors that influenced preoperative anxiety, such as the type of surgery and personality type.

\section{CONCLUSION}

In conclusion, respondents' ages in this study were averaged 36.65 years old, the gender majority was male, the education majority was junior high school, the job majority was employee, and the type of operation was tumor excision. The average anxiety score before the intervention was 14.71 , while in the control group was 15.71. Anxiety scores in both groups belonged to the moderate anxiety category. There were differences in anxiety scores before and after hypnotherapy and yoga combination therapy in the intervention group. There were differences in anxiety scores before and after deep breathing therapy in the control group. There was a significant decrease in anxiety scores after the application of hypnotherapy and yoga combination therapy. The researcher suggests future research to examine the effective duration of hypnotherapy and yoga combination therapy in preoperative patients.

\section{REFERENCES}

Asli, D.L. 2018, Kontekstualisasi ajaran yoga sutra patanjali pada masyarakat, Jayapangus Pres, Bali.

Azizah, L.M., Zainuri, I., \& Akbar, A. 2016, Buku ajar keperawatan kesehatan jiwa, Indomedia Pustaka, Yogyakarta.

Bradt, J., Dileo, C., \& Shim, M. 2013, 'Music interventions for preoperative anxiety ( Review )', Nursing and Health Professions, 6, 2.

Cahyadi, A. 2017, 'Metode Hipnoterapi Dalam Merubah Perilaku', Jurnal Ilmiah Syi'ar, 17(2),73.

Diananda, A. 2019, 'Psikologi remaja dan permasalahannya', Journal ISTIGHNA, 1(1),116133.

Firdaus, M.F. 2014, 'Uji validitas konstruksi dan reliabilitas instrumen the amsterdam preoperative anxiety and information scale (APAIS) versi Indonesia', Fakultas Kedokteran Universitas Indonesia, Program Studi Anestesiologi dan Intensif Terapi, Universitas Indonesia.

Gunawan, Y., \& Kristinawati, W. 2018, 'Regulasi emosi menghadapi kecemasan pada pasien pre operasi mayor', Jurnal Psikohumanika, 10(1) 42-61.

Hartoyo, E.P. 2015, 'Hubungan antara karakteristik demografi dengan pengetahuan mobilisasi dini pada pasien post operasi laparatomi di RS PKU Muhammadiyah Bantul', Universitas Muhammadiyah Yogyakarta.

Hawari, D. 2001, Manajemen stres cemas dan depresi, Fakultas Kedokteran Universitas Indonesia, Balai Penerbit FKUI, Jakarta.

Kinasih, A.S. 2010, 'Pengaruh latihan yoga terhadap peningkatan kualitas hidup', Bulutin Psikologi, 18, $1-12$.

Lestari, P., \& Putri, R.A. 2018, 'Kombinasi self hypnosis dan senam yoga terhadap tingkat nyeri dan kecemasan saat menstruasi', Indonesia Journal of Midwifery,1, 94-98.

Maryunani, A. 2014, Asuhan keperawatan perioperatif pre operasi, Trans info Media, Jakarta Timur.

Niken, P., Armiyanti, Y., \& Arif, S. 2014, 'Efektifitas waktu penerapan teknik relaksasi nafas dalam terhadap penurunan kecemasan pada pasien pre operasi bedah mayor abdomen di rsud tugurejo semarang', Jurnal Ilmu Keperawatan dan Kebidanan, 1-9.

Nurdin, R.O. 2018, 'Pengaruh teknik relaksasi nafas dalam dan aromaterapi lavender untuk penurunan tingkat kecemasan pasien pre operasi apendiksitis', Jurnal Media Kesehatan, 11(1),7984.

Pereira, L., Figueiredo-Braga, M., \& Carvalho, I.P. 2015, 'Preoperative anxiety in ambulatory surgery: the impact of an empathic patientcentered approach on psychological and clinical outcomes', Patient Education and Counseling, 6, 712.

Potié, A., Roelants, F., Pospiech, A., Momeni, M., \& Watremez, C. 2016, Hypnosis in the perioperative management of breast cancer surgery: clinical benefits and potential implications, 2016, 1-8. 


\section{B. BASIR ET AL.}

Rahmayati, E., Al Asbana, Z., \& Aprina 2017, 'Faktorfaktor yang berhubungan dengan lama perawatan pasien pasca operasi di ruang rawat inap bedah rumah sakit', jurnal keperawatan, XIII,(2), 195202.

Rismawan, W., Rizal, F.M., \& Kurnia, A. 2019, 'Tingkat kecemasan pasien pre-operasi di RSUD dr. Soekardjo Kota Tasikmalaya', Jurnal Ilmu Keperawatan, 19, 65-70.

Rizki, F.A., \& Hartoyo, M. 2019, 'Health education using the leaflet media reduce anxiety levels in pre-operation patients', Jendela Nursing Journal, 3(1), 49-57.

Rokawie, A.O.N., Sulastri, S., \& Anita, A. 2017, 'Relaksasi nafas dalam menurunkan kecemasan pasien pre operasi bedah abdomen', Jurnal Kesehatan, 8,(2), 257.

Sjamsuhidajat, R., \& de Jong, W. 2010, Buku ajar ilmu bedah, Penerbit Buku Kedokteran. Jakarta: EGC.

Smeltzer, S., \& Bare, B. 2002, 'Buku ajar keperawatan medikal bedah Brunner \& Suddarth, edisi' 8, EGC : Jakarta.

Sulastri, Cahyanti, A.I., \& Rahmayati, E. 2019, Perilaku caring menurunkan Kecemasan Pasien Preoperasi, 10( November), 382-389.

Syaripudin, A. 2018, Hipnoterapi aplikasi keperawatan komplementer, In Media, Bogor.

Téllez, A., Sánchez-jáuregui, T., Juárez-garcía, D.M., \& García-solís, M. 2016, 'Breast biopsy : the effects of hypnosis and music', International Journal of Clinical and Experimental Hypnosis, 4, 456-467.

Usnadi, U., Rahayu, U., \& Praptiwi, A. 2019, 'Kecemasan preoperasi pada pasien di unit One Day Surgery (ODS)', Jurnal Keperawatan 'Aisyiyah, 6, 75-87.

Vellyana, D., Lestari, A., \& Rahmawati, A. 2017, 'Faktor-faktor yang berhubungan dengan tingkat kecemasan pada pasienpPreoperative di RS Mitra Husada Pringsewu', Jurnal Kesehatan, 8(1), 108.

Yulinda, Purwaningsih, D., \& Sudarta, C.M. 2017, 'Latihan yoga dapat menurunkan tingkat kecemasan pada siklus mentruasi remaja puteri', Jurnal Ners dan Kebidanan Indonesia.

Yusuf, A., Fitryasari, R., \& Nihayati, H.E. 2015, Buku ajar keperawatan kesehatan jiwa, Salemba Medika, Jakarta Selatan. 